\title{
Equilibrium
}

Quarterly Journal of Economics and Economic Policy

VOLUME 9 ISSUE 1, 2014

p-ISSN 1689-765X, e-ISSN 2353-3293

www.economic-policy.pl

Gruszewska E. (2014), Changes in Informal Institutions in Poland and Transition Countries, "Equilibrium. Quarterly Journal of Economics and Economic Policy", Volume 9, Issue 1, pp. 39-55, DOI: http://dx.doi.org/10.12775/EQUIL.2014.003

\section{Changes in Informal Institutions in Poland and Transition Countries}

JEL Classification: $B 52, E 02, P 30$

Keywords: Institutions, Informal Institutions, Transition

\begin{abstract}
The research paper presents institutional systems of economies in the following transforming countries: Poland, the Czech Republic, Hungary, Slovakia, Estonia, Lithuania, and Latvia. The article aims at indicating the changes which have taken place in informal institutions' structures since the early nineties. It also attempts to determine how informal institutions are supporting formal institutions. Heading towards building new institutional systems, transforming countries face a barrier of slowly evolving informal institutions. A mismatch between institutional structures can be noticed in transforming countries. Low level of trust in people, resistance to new ideas, strong attachment to traditional behavioural patterns and excessive role of "connections", relatively low level of self-expression, high expectations towards the state and its welfare functions, and low social activity within the society, can be observed. The institutional changes in informal components have been presented using data from World Values Survey, CEPII and G.Hofstede research.
\end{abstract}

(C) Copyright Institute of Economic Research \& Polish Economic Society Branch in Torun Date of submission: March 1, 2013; date of acceptance: November 5, 2013

* Contact: gruszad@gmail.com, University in Bialystok, Faculty of Economics and Management, ul. Warszawska 63, 15-062 Białystok, Poland 


\section{Introduction}

Since the beginning of the 1990's the institutional systems in Central European and Baltic countries have experienced radical transformations. Change occurred throughout the whole spectrum of political and economic institutions. The transformations in the subsystems of formal and informal institutions did not take place all at once. While the changes in the former occurred relatively quickly, informal institutions evolved slowly, as is their nature, thus becoming a barrier in effective operations of institutional system of transition countries. As the formal institutions grew more similar to each other, Central European and Baltic countries adapted the approach of more developed countries. Informal institutions should also be expected to evolve in order to adapt to the administered constitutional approach.

In this light it seems necessary to indicate the changes in informal institutions which occurred in transition economies. It is important to determine whether these institutions complement the established formal institutions, for their common, one-way impact on economic activity allows achieving a more effective economy, measured by the dynamics of its GDB or GDP per capita.

\section{Methodology of the research}

This article will undertake the issue of the incongruity between informal institutions and formal institutions in Central European and Baltic countries. The study covered selected elements of informal institutional systems of Poland, Czech Republic, Slovakia, Hungary, Estonia, Lithuania, and Latvia.

Informal institutions were analysed using S. Kirdina's concept of an institutional matrix. It highlights those institutions which are specific for market economies, or the so called Y matrix institutions. These institutions usually comprise of formal (which generally are constituted, registered, and sanctioned by the state), and informal institutions (formed spontaneously in society, unwritten rules). The informal institutions are more difficult to capture. They are not incorporated or codified. The informal institutions often include ideological institutions, such as an individualistic approach or the subsidiarity principle. In a market economy, support for formal institutions comes from dominant values such as freedom, expansiveness, openness to change, novelty, creativity and originality (Kirdina 2010, p. 9). As such attitudes grow in strength, as these values are more firmly rooted in the minds of individuals and societies, they become a more durable support for the operations of economic and political institutions, which form the base of market econ- 
omies. The analysis evaluates social attitudes towards freedom, individualism, traditionalism, expressiveness, and confidence.

The aim of the undertaken considerations is to indicate the changes which have taken place in selected informal institutions of transition countries since the beginning of the 1990's. This will allow to determine whether these changes go in the direction observed in highly developed countries. The analysis of informal institutions of selected countries is based on the results of qualitative surveys conducted in the framework of World Values Survey, CEPII, and conducted by G. Hofstede.

\section{Informal institutions in the economic system}

In transition countries, constituted institutions were changed relatively quickly, although not every country could boast about the same effectiveness. Delaying changes or their gradual implementations would also mean the postponement of any benefits they brought. "The more of these reforms accumulate, and, of course, the earlier they do, the better for the development of the economy." (Balcerowicz 2010, p. 8). The countries which ceased its reforms, or introduced them more slowly, reported an increasing "institutional distance" compared to the countries which transformed faster (Rapacki 2009, p. 205). The speed of changes of the institutional subsystems in particular countries also varied. Intrinsically, informal institutions evolved, and are evolving more slowly. However, even here there have been noticeable changes in the last 20 years, which could indicate of an acceleration of the adaptation process. Transformations of institutions as well as their mutual adjustments are necessary to achieve a coherent, complete, efficient and balanced system. Such changes are fundamental factor of economic development (Wilkin 2007, p. 41). However, the problem lies in the fact that informal institutions are uncontrollable, and do not surrender easily to being transformed in a desired direction. It is difficult to indicate the factors affecting their transformation. The evolution of informal institutions is inscribed in the process of development of society, and the shaping of its consciousness. They are endogenic, and its players - the participants of economic processes, also influence their development.

Institutions are strongly embedded in the past, and that they have multilateral interactions. This makes a simultaneous change of all institutional elements impossible. The situation is especially visible when observing the transformations of formal institutions and the evolution of informal components of institutional systems. While formal institutions can be changed rela- 
tively quickly, transformation of their informal components takes place slowly, and they are hard to plan or direct. Informal institutions are "socially shared rules, usually unwritten, that are created, communicated, and enforced outside of officially sanctioned channels" (Helmke, Levitsky 2004, p. 727). They are inseparable with cultural changes. The inertia of the subsystem of informal components becomes a peculiar barrier for the effectiveness of the institutional system. The conflict between the two constituents of the system: formal and informal institutions inhibits the functioning of the whole setup. It can cause inactivity of or changes in informal institutions (Lissowska 2008, p. 93). The transaction costs of such institutional reconstruction will rise, adverse activities, corruption, and tax fraud strengthen (Fidrmuc, Gërxhani 2008, p. 266).

It should be good to indicate those informal institutions which support market economy. Their identification is possible thanks to an analysis of institutional systems of highly developed countries, which have built successful setups. S. Kiridina's theory of institutional matrix indicates ideological institutions, which are one of the three complementary groups, next to economic and political institutions. The author presents the institutional approaches characteristic of countries with an $\mathrm{X}$ matrix (centralized economies) and Y matrix (market economies). Among the ideological institutions specific to the $\mathrm{Y}$ matrix there are: individualism, diversity, freedom (Kirdina 2010, p. 9). Bernard Chavance points to numerous informal institutions whose impact on the economy is important enough for them to be subjected to research. Specifically, he focuses on such phenomena as corruption, tax evasion, informal economy, cronyism, but also trust, business ethics, informal cooperation (Chavance 2008, p. 57). In his research, Pasquale Tridico used an index of persistence of informal institutions, by which he measured the scale of people's attachment to old rules, resistance and inertia to institutional change, or the phenomenon of rent-seeking (Tridico 2006, p. 204).

Informal institutions are an important, albeit hard to study, element of the institutional order. They are a development of accepted and adopted systems of values. Changes in the hierarchy of values influence unwritten rules, and later the creation of a more formalized order. Legal regulations, general or particular, should be established on the basis of fundamental values. There is, of course, a visible influence of formal institutions on informal rules of behaviour.

Complementary informal institutions strengthen the activity of formal components of the system and allow for an efficient operation of the whole. In such case they form a strong system - an effective mechanism supporting the economy, providing intense stimuli that enhance economic activity and innovativeness. Achieving a specific institutional balance is a condition for a high-performing economy. 


\section{Complementarities of institutions?}

The changes which occurred in the Central European countries turned out to be a good observation field for accelerated changes of basic constituted institutions which form the market along with its environment, allowing an effective execution of law and constructing an efficient regulatory mechanism. As D. Rodrik points out, creating an efficient market economy requires the creation of several groups of significant institutions (Rodrik 2011, pp. 208-215):

- well protected property rights - these generate stimuli towards a dynamic economic activity, encouraging asset rotation and accumulation of value;

- regulatory institutions - regulate and improve the functioning of the economy;

- institutions for macroeconomic stabilization - decrease the threat of financial and economical stress and facilitate the economic process;

- institutions for social insurance - protect social groups from negative consequences of stratification of profit;

- institutions of conflict management - decrease transaction costs, increase the expansiveness of entities, and therefore develop entrepreneurship.

Thanks to these fundaments, the economy is able to gradually expand its development potential, to generate increasing profits, and to decrease the development distance. In Central European countries most of these changes were introduced over a short period of time and they were transplanted from highly developed economies. It was assumed that the time required for establishing individual constituted institutions, correspondent to slowly changing institutions deeply rooted in culture, would be too long, and its success rather uncertain and far from perfection. Therefore, changes were introduced at one time so that they could become construction elements of a new economic mechanism as fast as possible. Then came the difficult process of mutual adjustment of institutions. The functions of newly constituted institutions and the successful stimuli they generated still faced much difficulty. Fast changes in formal institutions was accompanied by degradation of unwritten rules and dynamic emergence of new, non-codified institutions (Chavance 2008, p. 65).

The construction of formal components omitted its incompatibilities with informal institutions. The speed of reforms was more important than a perfect incorporation of constituted institutions into the existing informal institutions. These unwritten rules formulate the behaviour of individuals and groups - they are automated and often non-conscious regulators of social life. Facing still relatively weak formal institutions, opportunistic behaviours emerged. "Institutions built upon wishful and not actual relations between individuals and groups cannot function well, if only because intellectual 
constructs, not verified in real life, reveal numerous, often deeply harmful, unforeseen consequences" (Winiecki 2010, p. 162).

Transition countries do not find it easy to uproot the attitudes that weakened the functioning of the young institutional system - informal institutions vestigial to the communist system - the patron - client order, amoral familism, corporatism (Małecki-Tepicht 2005, p. 49). Societies still retained informal ties between people, which strongly influenced their activities. In Poland we call it "znajomość" (connections), in Russia "blat", in Hungary "recombinant", in China "guanxi". These relatively formidable institutions functioned with newly established unwritten rules. Also, it was possible to observe their fast downfall (Chavance 2008, pp. 65-66). On the other hand, the gaps in formal institutions are filled relatively quickly with destructive informal institutions. Their use contributes to increasing the profits of individuals or certain groups at the expense of others (Puffer, McCarthy, Boisot 2010 , p. 442). Informal institutions which were shaped in the previous system also influence the efficiency of new formal institutions. However, under conditions of high uncertainty, caused also by the incompleteness of constituted institutions contradictoriness of the stimuli they generate, entities return to previously formed behaviours that used to work in the past (Platje 2007, pp. 32-33). In time, the more stable actions of constituted institutions decrease the scale of this process. The move from informal non-codified laws to formal codified laws is a slow process.

\section{Freedom and individualism in transition countries}

In the face of the initial transformation chaos, the activities of entities were burdened with uncertainty. Informal institutions such as "connections" formed a specific safety buffer, which was gradually eliminated as the gaps in formal institutions were filled and its functions improved. People started to see the opportunities of personal gains in not complying with constituted norms. More so, the long years of the shortage economy taught people to deal with difficulties, also in ways which did not follow the law. Undoubtedly, the beginning of the transformation is a period of a strong growth in the dynamics of economic activity, which effected in increased scope of economic freedom. Attitudes such as "taking matters into one's own hands" snowballed active behaviours directed at the development of the so-called private initiative. It would seem that entrepreneurial attitudes became social norms, more and more common. 
One of the basic institutions at the foundation of a market economy is economic freedom. The societies of transition counties, in most cases, treat freedom as a category of higher importance than equality for the development of a country (Graph 1). At the initial stages of transformation people demanded more freedom, because it allowed them to fulfil their individual goals. Freedom meant separation from the previous system. The years that followed revealed numerous faults in the functions of those economies. Transition societies found that the new market economy institutions are unable to quickly ensure a stable economic growth and neither do they warrant economic security. Privatization, deregulation, and other changes in the formal sphere in the short period did not entail establishing a functional economical system. Reality turned out to be different from expectations. New economic problems emerged, social conflicts rose. Countries had to deal with decreases in production and profit dynamics.

Figure 1. Freedom and equality. The percentage of people who indicated that freedom is more important than equality in 1990-2008

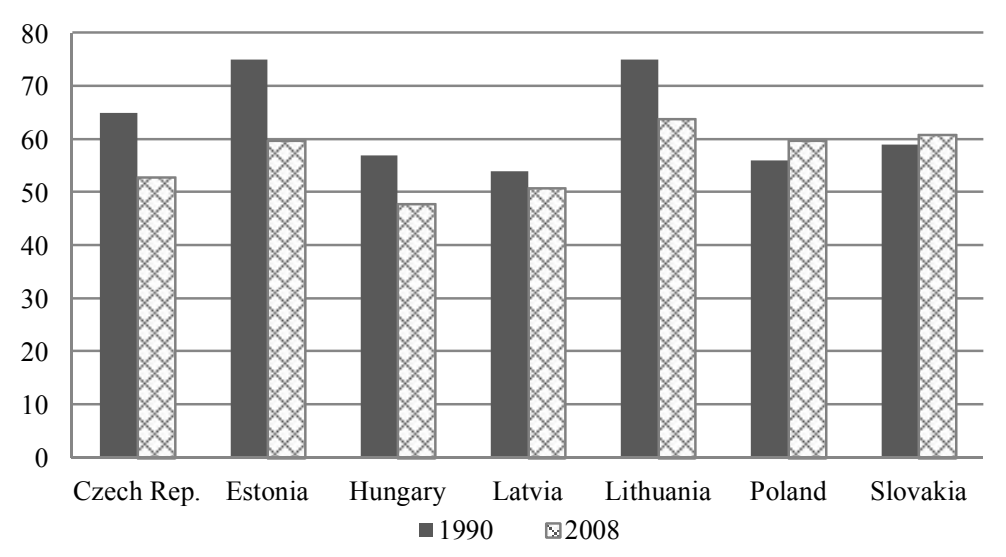

Source: own work based on Atlas (30.12.2012).

In many countries, the percentage of people who indicated that freedom is more important than equality is grater that $60 \%$ in, for example, Great Britain, Norway, Sweden, Holland. Among the studied transition countries, only Lithuania and Slovakia showed a similar indication. Only two countries, Poland and Slovakia, demonstrated a growth of this ration in 19902008. The other countries exhibited a growth in the number of people who found equality more important that freedom. It seems that the weakening of freedom in the hierarchy of values could be caused by a critical assessment 
of the economic situation, decrease of economic security, increase of risk in individual businesses, and growth of the rate of demanding attitudes towards the state.

Figure 2. Individualism and the state. The percentage of people who believe that the state should control firms more effectively* in 1999-2008

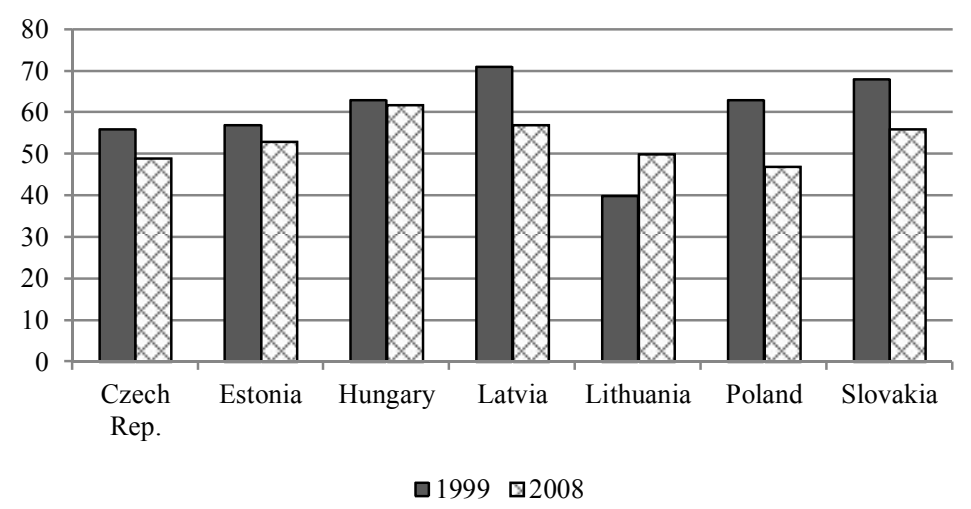

*The surveyed were asked to give their opinion on whether it was necessary for the state to
intervene in business. The opinion was expressed in a $0-100$ scale $(0$ meaning that the state
should give more freedom to firms, 100 meaning that the state should exercise more control
over companies).

Source: own work based on Atlas (30.12.2012).

All of the surveyed countries except Lithuania demonstrated a decrease in the percentage of people who believe that state control of business should increase (Graph 2). Still, many respondents believe that state should provide support for businesses (the highest ratio of such people is in Hungary $-60 \%$ ). In 2008, $47 \%$ of Polish respondents believed that the state should control companies more effectively. The others believed that the more freedom businesses are left with, the better.

Most transformation societies hold the belief that they have a bigger influence on their lives, that they possess freedom of choice and control over their lives. Two of the surveyed countries presented a decrease in the percentage of people who believe that the state should control firms more effectively (the Czech Republic and Latvia). In 2008, in all of the surveyed countries except Latvia (58\%) this indicator exceeded $60 \%$, and was the highest in Lithuania (67\%) and Slovakia (66\%) (Graph 3). These numbers are comparable with the figures from highly developed European countries. Still the highest level is reported from Scandinavian countries - exceeding 70\% (75\% 
Denmark, 74\% Sweden, 73\% Norway and Finland) (Atlas, 30 December 2012).

Figure 3. The percentage of people who believe that they have complete freedom of choice and control over their lives in 1990-2008

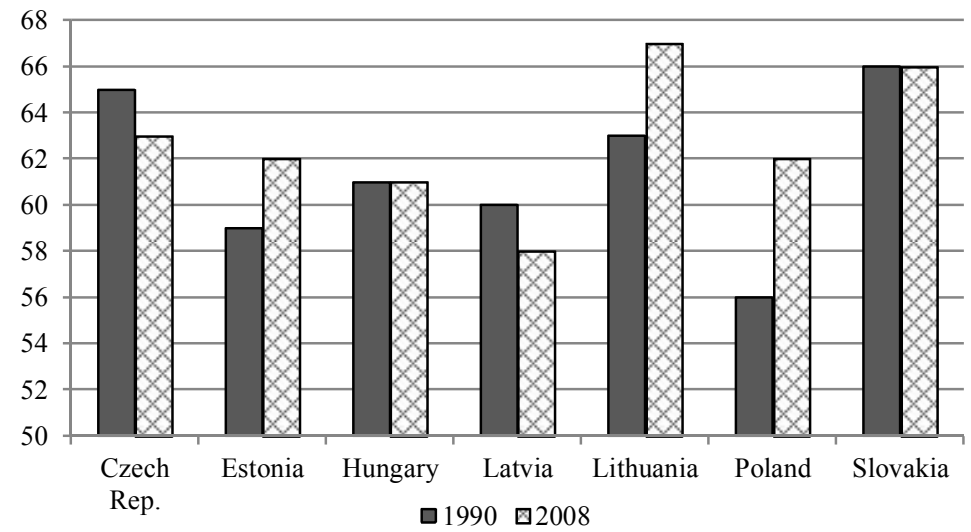

Source: own work based on Atlas (30.12.2012).

The indicators for Central European and Baltic countries confirm the importance of individualism as a dominant attitude. The disclosure of individualistic attitudes was possible thanks to changes in formal institutions - a gradual elimination of barriers connected with business activity. This is clearly visible in the rise in position in freedom indices by transition countries. The largest progress in the freedom index belongs undisputedly to Lithuania, which in 1996-2013 advanced by 83 positions in the Heritage Foundation ranking, and by 65 position in the Fraser Institute ranking (Table 1). The other transition countries also achieve better results in creating a liberal economic environment.

The dynamics of freedom indices in those countries is higher than in others, resulting those countries progressing in the rankings. In 1990-2013, Poland advanced by 56 positions in the Fraser Institutes ranking of freedom of conducting business activity, and by 20 positions in the Heritage Foundation list (Economic Freedom 2 January 2013); Index of Economic Freedom (10 January 2013). These processes should be related to the increase in the quality of institutions. 
Table 1. Change in the level of economic freedom in transition countries according to Heritage Foundation and Fraser Institute in 1995-2013

\begin{tabular}{|l|c|c|c|c|}
\cline { 2 - 5 } \multicolumn{1}{c|}{} & \multicolumn{2}{l|}{$\begin{array}{l}\text { Heritage Foundation } \\
\text { Index IEF (rank) }\end{array}$} & \multicolumn{2}{l|}{$\begin{array}{l}\text { Fraser Institute } \\
\text { Index EFW (rank) }\end{array}$} \\
\cline { 2 - 5 } & $\begin{array}{l}\mathbf{2 0 1 3}(\mathbf{1 7 7} \\
\text { countries) }\end{array}$ & $\begin{array}{l}\mathbf{1 9 9 5}(\mathbf{1 0 0} \\
\text { countries) }\end{array}$ & $\begin{array}{l}\mathbf{2 0 1 2}(\mathbf{1 4 4} \\
\text { countries) }\end{array}$ & $\begin{array}{l}\mathbf{1 9 9 5}(\mathbf{1 2 3} \\
\text { countries) }\end{array}$ \\
\hline Estonia & $75,3(13)$ & $65,2(26)$ & $7,74(14)$ & $5,8(72)$ \\
\hline Czech Rep. & $70,9(29)$ & $67,8(24)$ & $7,16(58)$ & $5,7(73)$ \\
\hline Lithuania & $72,1(29)$ & $49,7(105)$ & $7,54(28)$ & $5,2(93)$ \\
\hline Latvia & $66,5(55)$ & $55,0(87)$ & $7,12(61)$ & $5,4(83)$ \\
\hline Poland & $66,0(57)$ & $50,7(77)$ & $7,31(48)$ & $5,2(89)$ \\
\hline Slovakia & $68,7(42)$ & $60,4(47)$ & $7,45(33)$ & $5,4(81)$ \\
\hline Hungary & $67,3(48)$ & $55,2(63)$ & $7,08(64)$ & $6,1(61)$ \\
\hline
\end{tabular}

Source: own work based on Economic Freedom (2.01.2013); Index of Economic Freedom (10.01.2013).

Increase importance of freedom and individualism seems to be a change correspondent with the idea of market economy, where egoistic interests are the driving force behind the economic mechanism. Individualism is also considered to be one of the main factors among informal areas of business activities which influences the long term dynamics of the economy (Gorodnichenko, Roland 2011, p. 497). It can be assumed that also in transition countries, an increase in individualistic attitudes directed at the realization of own goals will also be a beneficial factor for economic growth in the long term.

The position of individualism as opposed to collectivism can be found in the analysis of cultural aspects by G.Hofstede. The results of those studies indicate a high position of individualism among the studied societies. The highest index of individualism was demonstrated by Hungary (80), followed by: Estonia (69), Poland (60), the Czech Republic (58), and Slovakia (52). In comparison, several highly developed societies present similar results (Germany 67, France 71). However, there are also counties with a much higher lead of individualism over collectivism (USA 91, Great Britain 89) (National, 3 October 2013). It is therefore clear that the strength of individualistic goes in tandem with economic dynamics.

The increase of economic freedom is a factor promoting entrepreneurship. The communities of transition countries show a successive process of growth of the importance of individualism and expressiveness, as demonstrated in the activity, which gradually replaces conservatism. It does not matter whether the attitude towards economic activity changed. People became more active because they knew that more activity could be more beneficial. The increase of freedom became a catalyst of the previously non- 
manifested attitudes. One of the most basic barriers of entrepreneurship in planned economies - its penalisation - was removed (Winiecki 2013, p. 203).

\section{Postmaterialistic values in transition countries}

Societies in counties with higher incomes are usually more tolerant, open to novelty, and trusting. They are more prone to expressive attitudes directed at self-expression and realization of individual goals. Citizens exhibit a higher participation in social live, contribute to various organizations, and want to have an effect on what is happening in their country (Inglehart, Welzel 2009, pp. 37-38). An increase in income is accompanied by changes in the system of values, and in formal and informal rules that regulate the functioning of the society and economy. Inglehart and Welzel's research conducted on the basis of World Values Survey studies indicate that many changes in the systems of values in post-communist Europe are directed towards postmaterialism observed in Western Europe (Inglehard, Welzel 2009, p. 40).

The transition of a materialistic society to a postmaterialistic society is manifested in their gradual loss of importance economic factors in their choices. In the cultural sphere, there is a shift of values - inhibiting, forbidding norms (order, equality, self-discipline, strong subordination to group rule) towards liberal values (pluralism, freedom tolerance, openness) (Ryk 2004, p. 139). Postmaterialistc values also include social confidence, selfdeciding and independence, ecology, minority rights, freedom of choice, tolerance, life satisfaction, and self-expression.

The research conducted by Ronald F. Inglehart and Christian Welzel indicates that a lot of the changes in transformation counties are concurrent with the tendencies characteristic of highly developed countries. This trend convers increased expansiveness (and, at the same time, decreased conservatism) and dissemination of rationalistic-secular values which replace traditionalism (Gruszewska 2012, pp. 74-78).

The transition period saw a clash of two attitudes, and consequently, two mechanisms. Groups of people strongly attached to traditionalist values, devoted to habits shaped by generations, met with other attitudes - attitudes concerned with making money, and therefore connected with the economic market. "This struggle must be lost by the followers of traditionalistic values, as they become easy prey for homo oeconomicus creativus" (Woźniak 2011, p. 290). 
Figure 4. Changes in systems of values in transition countries in 1990-2000*

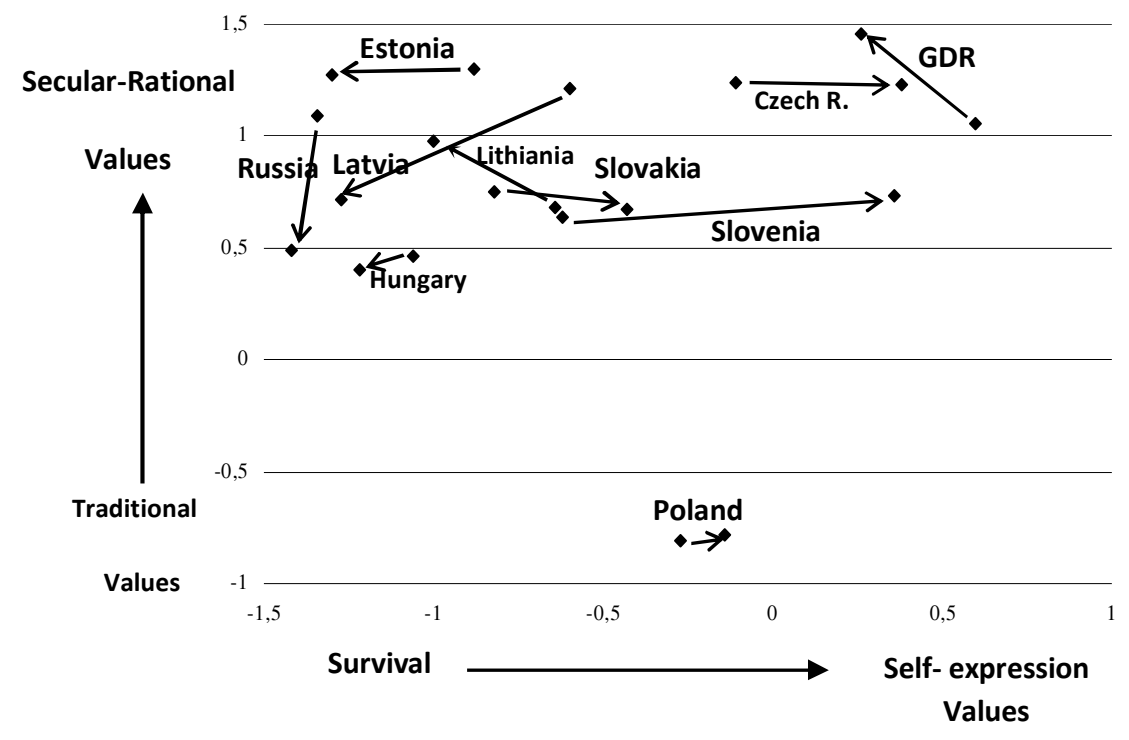

* Poland, GDR, Slovenia, Russia - 1990-2006, Estonia 1990-1995

Source: Inglehart, Welzel 2010 Supplementary data, based on World Value Survey.

In Poland, compared to other surveyed states, there is a clear and strong attachment to traditional, national values. This expresses itself in close family ties, strong religiousness and national identity. Although there is an upward shift (increased importance of rational values), the influence of traditional values on people's actions remains strong (Graph 4). Among the surveyed countries, Latvia, Hungary, and Estonia exhibited a growth in the importance of traditionalistic values. As for expansionism, which strongly affects changes in income (Gruszewska 2012, p. 78), its increase was observed in Poland, the Czech Republic, Slovakia (also in Slovenia).

Other studies (Institutional Profiles) indicate that transition countries demonstrate a decrease of traditionalism, similar to highly developed countries (Table 2). For example, in Germany and Norway in 2012 this index was at 0.0 , and in Belgium and Finland it was at 1 . It can be said that a large portion of transition societies exhibits a similar index. In Poland there is a noticeably higher solidarity with traditional institutions (family, neighbourhood, religion). This attitude, however, is slightly less connected to economic dynamics than expressionism (Gruszewska 2012, pp. 78-79). On the other hand, the same index (3.33) is noted in, for example, Spain or Japan (Institutional 12.10.2013). 
Table 2. Traditional solidarity index in the analysis of institutional CEPII profiles of transition countries in 2001-2012

\begin{tabular}{|c|c|c|c|}
\hline Year & $\mathbf{2 0 0 1}$ & $\mathbf{2 0 0 6}$ & $\mathbf{2 0 1 2}$ \\
\hline Czech Rep. & 2,46 & 2,49 & 1,00 \\
\hline Hungary & 4,00 & 2,00 & 1,33 \\
\hline Poland & 3,46 & 3,49 & 3,33 \\
\hline Lithuania & 4,00 & 3,49 & 1,33 \\
\hline Germany & 2,46 & 2,49 & 1,00 \\
\hline France & 4,00 & 2,00 & 1,33 \\
\hline United States & 3,46 & 3,49 & 3,33 \\
\hline
\end{tabular}

Source: own work based on Institutional (12.10.2013).

When establishing new institutional systems, transforming countries face the barrier of low social confidence. Low levels of confidence are characteristic of societies whose members are attached to traditional, religious values, usually with strong family ties. Such groups are unfavourable of opening to innovation, they seldom undertake new challenges and search for creative solutions. Low confidence towards others makes it difficult to expand their business activity to unknown areas, and is a barrier to establishing cooperation with new partners. In the face of decreasing social confidence, rentseeking becomes more prevalent (Woźniak 2011, p. 298).

Along with increased income per capita, which increases economic security, it would seem that trust towards others should also rise. It is usually accompanied by evaluated increased probability of gains, and allows for a more effective forecast of the behaviours of others (Wang, Gordon 2011, p. 584). This is one of the basic indicators of undertaking economic activity.

In the surveyed period, the percentage of people who trust others in transition countries decreased in four of them, most prominently in Slovakia and Hungary, increased in three countries: the Czech Republic, Estonia and Latvia (Graph 5). In most Western European countries, this index is higher, for example in Denmark $-76 \%$, Norway $-74 \%$, Sweden $-70 \%$, Finland $-68 \%$, Holland $-63 \%$. The scale is at least 2 or 3 times higher than in the surveyed countries, and compared to the index in Slovakia, it is 6 times higher. 
Figure 5. Trust in other people. Percentage of people who agree to the question: "can people be trusted?" in 1990 and 2008

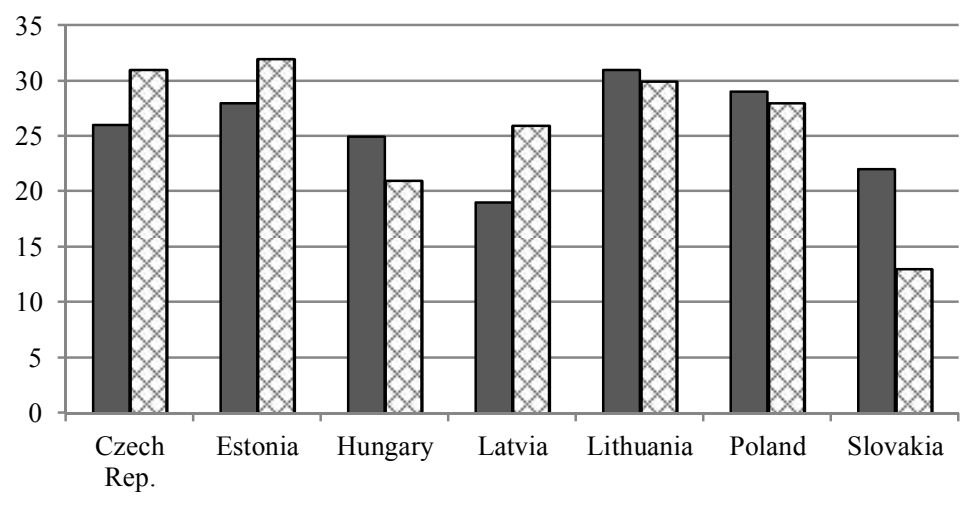

口1990 ロ2008

Source: own work based on Atlas (30.12.2012).

Trust in other people is strongly correlated with informal institutions (Knowles, Weatherston 2006, p. 5). Higher level of trust allows to undertake large scale economic endeavours, enables achieving high economic dynamics. The studied transition countries expressed a lower confidence towards others than in highly developed societies. This fact can be treated as a barrier for achieving institutional balance. Societies in transformation countries are also characterized by low evaluation of formal institutions, and therefore low confidence in them. For example, in most of the surveyed societies less than $40 \%$ of the population expressed confidence in the justice system. In 2008 it was the lowest in Lithuania (25\%) and the highest in Estonia (54\%) (Graph 6). In highly developed European states this index usually sets at more than $50 \%$, like for example in France or Germany, whereas in Scandinavian countries it is even higher (exceeding 70\%) (Atlas 30 December 2012).

It must be stressed that the construction of a proper system of law is not sufficient to create a stable economic environment. An effective justice system is equally important for detecting any derogations from the established rules. It is worth noticing how people rate its efficiency and whether they have a corresponding confidence in the justice system. The higher the confidence in the fact that law acts as a positive regulator of economic activity and that the state is able to efficiently eliminate undesirable behaviours, the fewer incongruities between formal and informal institutions. In the face of low social confidence, it surely is more difficult to achieve a effective operation of formal approaches. In Poland and in other transformation states, it is not the formal institutions that are the problem, but rather the informal ones. People in these societies are still characterised by low political and citizen culture. They cannot cooperate to achieve common goals, often because of 
the lack of confidence. There is a lot more activity in protests against something than actions directed towards a socially beneficial objective (Abramczuk 2012, pp. 260-261).

Figure 6. Confidence the justice system. Percentage of people who express confidence in the justice system in 1990 and 2008

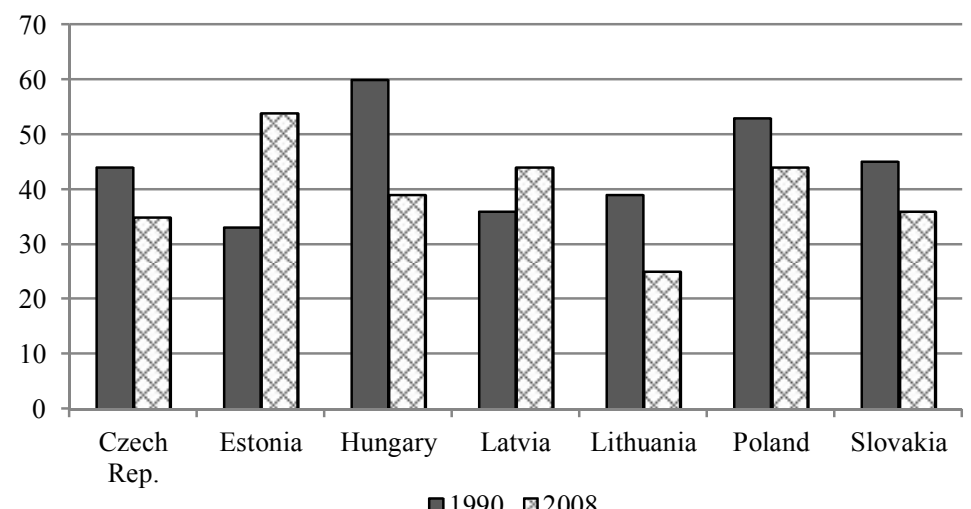

Source: own work based on Atlas (30.12.2012).

\section{Conclusions}

The studies conducted in this article allow to conclude that informal institutions in transforming countries have changed in the direction observed in highly developed countries. Still, however, they form a barrier in the efficient functioning of formal institutions. The people in these countries are still too attached to a state - the institution which is a remedy for every difficulty in economic activity. They are also reluctant to act at their own expense. A large percentage of people believe that the state should support and control business activities (almost 50\%). They are not confident in others (on average only $25 \%$ have confidence in others), and are also characterized by a strong attachment to traditionalist thinking, which surely inhibits large scale business activities, expanding outside their local areas, and acquiring new markets. However, it is noticeable that in most transforming countries people believe that they have a large influence on their lives and on the decisions they make (more than $60 \%$ of respondents). There is an observed growth of expressiveness in most of the presented societies. 
Changes in informal components of institutions in transformation countries occur relatively slowly and have not reached a level that could be considered desirable. The period of the changes is still short. It may well be expected that these processes will proceed with similar intensity, allowing for a fuller mutual adjustment between formal and informal institutions.

\section{References}

Abramczuk K. (2012), Zaufanie do instytucji polskiego państwa [in:] Jarosz M. (ed.), Instytucje: konflikty i dysfunkcje, Oficyna Naukowa, ISP, Warszawa. Atlas of European Values, http://www.atlasofeuropeanvalues.eu/new/ (30.12.2012). Balcerowicz L. (2010), Transformacja gospodarcza w Europie ŚrodkowoWschodniej: Wnioski z 20 lat doświadczeń, „Ruch Prawniczy, Ekonomiczny i Socjologiczny", Vol. 72, No. 2.

Chavance B. (2008), Formal and informal institutional change: the experience of postsocialist transformation, "The European Journal of Comparative Economics", Vol. 5, No. 1.

Economic Freedom of the World 2012, Fraser Institute http://www.freetheworld.com/index.php (02.01.2013).

Fidrmuc J., Gërxhani K. (2008), Mind the gap! Social capital, East and West, "Journal of Comparative Economics" Vol. 36, http://dx.doi.org/10.1016 j.j.je.2008.03.002.

Gorodnichenko Y., Roland G. (2011), Culture, Institutions, and Development. Which Dimensions of Culture Matter for Long-Run Growth?, "American Economic Review", Vol. 101, No. 3.

Gruszewska E. (2012), Transformacja instytucji nieformalnych w Polsce, "Gospodarka Narodowa", No. 3.

Helmke G., Levitsky S. (2004), Informal Institutions and Comparative Politics: A Research Agenda, „Pespectives on Politics”, Vol. 2, No. 4.

Index of Economic Freedom 2013. Heritage Foundation: http://www.heritage.org/ index/explore (10.01.2013).

Inglehart R.F., Welzel Ch. (2009), How Development Leads to Democracy. What We Know About Modernization, "Foreign Affaris", Vol. 88, No. 2.

Inglehart R.F., Welzel Ch. (2010), The WVS Cultural Map of the World, http://www.worldvaluessurvey.org/wvs/articles/folder_published/article_base_54

Institutional Profiles Database, CEPII, http://www.cepii.fr/institutions/EN/ipd.asp (12.10.2013).

Kirdina S. (2010), Prospects of Liberalization for S\&T Policies in Russia: Institutional Analysis, „Sociology of Science and Technology”, Vol. 1, No. 2.

Knowles S., Weatherston C. (2006), Informal Institutions and Cross-Country Income Differences, "Credit Research Paper" No. 06/06.

Lissowska M. (2008), Instytucje gospodarki rynkowej w Polsce, C.H.Beck, Warszawa.

Małecki-Tepicht S. (2005), Instytucje - fundament, czy fasada? [in:] Instytucje - fundament czy fasada polityki makroekonomicznej? WNE UW, Warszawa 
National cultural dimensions, http://geert-hofstede.com/national-culture.html (03.10.2013).

Platje J. (2007), Bodźce i koszty transakcyjne a zmiany instytucjonalne oraz stan polskiej gospodarki w latach 1970-2000, Wyd. UO, Opole.

Puffer S.M, McCarthy D., Boisot M. (2010), Entrepreneurship in Russia and China: The Impact of Formal Institutional Voids, "Entrepreneurship Theory and Practice", Vol. 34, No. 3.

Rapacki R. (2009), Reformy instytucjonalne a zróżnicowanie ścieżek wzrostu gospodarczego w krajach transformacji w latach 1990-2005 [in:] Rapacki R. (ed.), Wzrost gospodarczy w krajach transformacji. Konwergencja czy dywergencja?, PWE, Warszawa.

Rodrik D. (2011), Jedna ekonomia, wiele recept. Globalizacja, instytucje i wzrost gospodarczy, Wyd. Krytyki Politycznej, Warszawa.

Ryk A. (2004), Pokolenie zmiany: studium porównawcze wartości i perspektyw życiowych młodzieży włoskiej i polskiej, WN Akademii Pedagogicznej, Kraków.

Tridico P. (2006), Institutional Change and Governance Indexes in Transition Economies: the case of Poland, "The European Journal of Comparative Economics", Vol. 3, No. 2.

Wang L., Gordon P. (2011), Trust and institutions: A multilevel analysis, "The Journal of Socio-Economics", Vol. 40, No. 5.

Wilkin J. (2007), Rynek, państwo i spoleczeństwo w Polsce: dojrzewanie równowagi instytucjonalnej [in:] Kleer J., Kondratowicz A. (eds.), Gospodarka i demokracja w Polsce. Dojrzatość i trwałość instytucji, CeDeWu. pl, Warszawa.

Winiecki J. (2010), Odwieczne zderzenie wyobrażeń o tym, jak funkcjonuje świat. Kontrast wizji i proponowanych instytucji, „Ruch Prawniczy, Ekonomiczny i Socjologiczny", Vol. 72, No. 3.

Winiecki J. (2012), Transformacja postkomunistyczna. Studium przypadku zmian instytucjonalnych, Wyd. C.H.Beck, Warszawa.

Woźniak M.G. (2011), Gospodarka Polski 1990-2011, Vol.1 Transformacja, PWN, Warszawa. 